\title{
A POSIÇÃO DO MAGISTRADO FRENTE AOS NEGÓCIOS JURÍDICOS PROCESSUAIS
}

THE JUDGE'S POSITION FACING PROCEDURAL AGREEMENTS

José Miguel Garcia Medina ${ }^{1}$

Amanda Meger Cappellazzo ${ }^{2}$

\section{RESUMO}

O presente estudo aborda os negócios jurídicos processuais como ferramenta para promoção de um processo mais justo e adequado ao direito material postulado, trabalhando a cláusula geral do artigo 190 do CPC/2015, o princípio do autorregramento da vontade das partes e, como foco principal, a atuação do magistrado frente aos negócios jurídicos processuais, que a partir dos preceitos trazidos pelo Novo Código e pelo princípio da cooperação, deve dialogar com os participantes do processo.

Palavras-Chave: Novo Código de Processo Civil; Negócios Jurídicos Processuais; Flexibilização Procedimental; Poderes do Juiz; Princípio da Cooperação.

\begin{abstract}
This paper approaches the procedural agreements as a tool to promote a more fair and adequate procedure to the claimed Substantive Law, analyzing the general clause of article 190 of the CPC/15, the principle of self-regulation of the parties' will and, with special focus on the judge's conducts when facing the procedural agreements, which should dialogue with the Parties of the procedure, in light of the new concepts endorsed by the New Code and the principle of cooperation.
\end{abstract}

Keywords: New Code of Civil Procedure; Procedural Agreements; Procedural Flexibilization; Powers of the Judge; Principle of Cooperation.

\section{INTRODUÇÃO}

\footnotetext{
${ }^{1}$ Doutor e Mestre em Direito pela PUC-SP. Professor do Mestrado em Direito Processual e Cidadania da Unipar. Advogado.medina@medina.adv.br

${ }^{2}$ Mestranda em Direito Processual Civil e Cidadania pela UNIPAR. Especialista em Direito Processual Civil. Advogada militante. E-mail: amandamcappellazzo@gmail.com.
} 
Mudanças de comportamento e cultura nas sociedades devem vir acompanhadas de mudanças legislativas que rompem com o sistema vigente em busca da adequada tutela jurisdicional em consonância com as garantias fundamentais e de acesso à justiça.

É neste sentido que o Código de Processo Civil de 2015 rompe com o estrito sistema da legalidade das formas e passa a buscar meios de assegurar às partes uma justiça mais célere e efetiva, em conformidade com o direito material postulado e suas especificidades, através da adoção de procedimentos diferentes daqueles dispostos em lei, dando uma nova roupagem a declaração da vontade das partes dentro do processo e fazendo uma releitura da atividade jurisdicional através da cobrança de uma atuação ativa do Juiz na efetivação dos direitos das partes.

Em seus artigos 190 e 200, o novo código traz três novidades que quebram com a cultura de um processo engessado e estanque, sendo elas: o princípio da adequação procedimental, a inserção de cláusula geral de atipicidade dos negócios processuais e o princípio do autorregramento da vontade das partes.

Essa possibilidade de as partes estabelecerem regras processuais trouxe importantes discussões na comunidade jurídica, que discorre avidamente acerca dos limites do autorregramento da vontade das partes, sobre a cláusula legal do art. 190 do CPC, o instrumentalismo processual e a atribuição das partes frente aos negócios jurídicos processuais, especialmente qual os limites da atuação do juiz, que hora atua como parte no processo e hora como fiscal da lei.

Neste sentido, faz-se importante o estudo acerca do papel do juiz como participante do diálogo processual com vista a noção de processo colaborativo que conta com a participação de todos os sujeitos do processo, partes e juiz, na construção de uma decisão judicial adequada ao direito material postulado.

\section{DA TEORIA DOS FATOS JURÍDICOS}

Antes de iniciar o estudo dos poderes do juiz frente aos negócios jurídicos processuais propriamente ditos, se faz necessário pontuar a definição de fato jurídico e seus desdobramentos nos termos elaborados por Pontes de Miranda em sua obra "Tratado de Direito Privado: Parte Geral, Tomo II" e desenvolvida por Marcos Bernardes de Mello, na obra "Teoria do Fato Jurídico: Plano da Existência", autoridades sobre o tema.

A regulamentação dos fatos através da imposição de norma jurídica é essencial à sociedade em que vivemos. É a partir do estabelecimento de condutas que impõe ordem e que 
sejam incondicionais e independentes de adesão que se evita o caos social e se proporciona uma coexistência harmônica em sociedade ${ }^{3}$.

A valoração dos fatos relevantes para os relacionamentos humanos através das normas jurídicas fazem nascer os fatos jurídicos, que passam a partir deste momento, a fazer parte do mundo jurídico, juntamente com seus direitos, deveres, prestações e obrigações ${ }^{4}$.

Discorrendo sobre a conceito de fatos-jurídicos, Leonardo Carneiro da Cunha dispõe que "os fatos tornam-se jurídicos pela incidência das normas jurídicas que assim os assinalam. Previsto o fato no enunciado normativo, sua ocorrência faz incidir a norma, daí surgindo o fato jurídico"5.

Propriamente, Pontes de Miranda conceitua os fatos jurídicos da seguinte forma:

\begin{abstract}
“já vimos que o fato jurídico é o que fica do suporte fáctico suficiente, quando a regra jurídica incide e porque incide. Tal precisão é indispensável ao conceito de fato jurídico. Vimos, também, que no suporte fático se contém, por vezes, fato jurídico, ou, ainda, se contêm fatos jurídicos. Fato jurídico é, pois, o fato ou complexo de fatos sobre o qual incidiu a regra jurídica; portanto, o fato de que dimana, agora, ou mais tarde, talvez condicionalmente, ou talvez não dimane, eficácia jurídica. Não importa se é singular, ou complexo, desde que, conceptualmente, tenha unidade" $"$.
\end{abstract}

Seguindo a linha de pensamento destes doutrinadores, para abranger todas as categorias de fatos jurídicos, identifica-se os fatos jurídicos lato sensu a partir de elementos essenciais “ "a) a conformidade ou não conformidade com o fato jurídico com o direito, b) a presença, ou não, de ato humano volitivo no suporte fático hipotético"7.

No tocante aos fatos contrários ao direito, estes não serão melhor tratados no presente trabalho, visto que não encontram relação com os negócios jurídicos processuais. Já os atos em conformidade com direito, analisando-os a partir da presença, ou não, de "ato humano volitivo à base do suporte fáctico" e ato jurídico lato sensu, que comportará os atos jurídico stricto sensu e os negócios jurídicos, alvo da presente exposição.

De forma sucinta, o ato jurídico em seu sentido stricto sensu compõem-se de fatos da natureza, não exigindo para sua existência os atos humanos, mesmo que este influa em sua origem, como por exemplo, o nascimento ou a morte, se provocada por ato humano ${ }^{9}$.

\footnotetext{
${ }^{3}$ MELO, Marcos Bernardes de. Teoria do fato jurídico: plano da existência. 7. ed. São Paulo: Saraiva, 1995.

${ }^{4}$ Ibid.

${ }^{5}$ CUNHA, Leonardo Carneiro da. Negócios jurídicos processuais no processo civil brasileiro. In: CABRAL, Antonio do Passo; NOGUEIRA, Pedro Henrique (Org.). Negócios processuais. 3. ed. Salvador: Juspodivm, 2017, p. 39-74.

${ }^{6}$ MIRANDA, Pontes de. Tratado de direito privado. 60. ed. Campinas: Bookseller, 2000, p. 126.

${ }^{7}$ MELO, op. cit., p. 94.

${ }^{8}$ Ibid., 99.

${ }^{9}$ Ibid.
} 
Já o ato-fato jurídico é formado por conduta humana, mas não leva em consideração a vontade de praticar o ato, mas tão somente os efeitos na esfera jurídica que dele emanam ${ }^{10}$.

No tocante aos atos jurídicos lato sensu, nas palavras de Marcos Bernardes de Melo “denomina-se ato jurídico o fato jurídico cujo suporte fáctico tenha como cerne uma exteriorização consciente de vontade, dirigida a obter um resultado juridicamente protegido ou não proibido e possível" ${ }^{11}$. Essa manifestação da vontade é considerada imprescindível para sua caracterização e de suas subespécies, os atos jurídicos stricto sensu e os negócios jurídicos.

Os atos jurídico stricto sensu são verificados nos casos em que a manifestação da vontade encontra embasamento legal em uma categoria jurídica, ou seja, seus efeitos estão definidos juridicamente ${ }^{12}$, “razão pela qual são invariáveis e inexcluíveis pelo querer do interessado, donde dizer-se que são efeitos necessários, ou ex lege" ${ }^{\text {"13 }}$.

Já os negócios jurídicos destacam-se por zelar pela liberdade de celebração entre as partes através de uma declaração de vontade visando a produção de efeitos jurídicos determinados. Estes negócios, regidos por normas cogentes, não são ilimitados, tratando o ordenamento de limitar o poder dispositivo ${ }^{14}$.

Objetivando a preservação da liberdade “concebeu-se o negócio jurídico como instrumento de realização da vontade individual, respaldando uma liberdade contratual que se queria praticar sem limites." 15

Transportando esses conceitos para a teoria geral do processo, levando em consideração que o processo somente se desenvolve por intermédio de um procedimento prédeterminado por norma cogente, nos atos jurídicos stricto sensu a atuação das partes encontramse previamente definida, não havendo espaço para disposição sobre seus efeitos ${ }^{1617}$.

\footnotetext{
${ }^{10}$ BRAGA, Paula Sarno. Primeiras reflexões sobre uma teoria do fato jurídico processual: plano da existência. Revista de Processo, São Paulo, v. 148, p.293-320, jun. 2007.

${ }^{11}$ MELO, Marcos Bernardes de. Teoria do fato jurídico: plano da existência. 7. ed. São Paulo: Saraiva, 1995, p. 117.

${ }^{12}$ BRAGA, op. cit.

${ }^{13}$ MELO, op. cit., p. 127.

${ }^{14}$ BRAGA, op. cit.

${ }^{15}$ MELO, op. cit., p. 140.

${ }^{16}$ MEDINA, José Miguel Garcia. Curso de direito processual civil moderno. 3. ed. São Paulo, 2017.

${ }^{17}$ Com a incorporação dos fatos jurídicos pela teoria geral do processo tem-se o fato jurídico processual em sentido lato, o que, nas palavras de Paula Sarno Braga "Seria ele o fato ou completo de fatos que, juridicizado pela incidência de norma processual, é apto a produzir efeitos dentro do processo." A mesma estudiosa complementa que estes atos podem acontecer intraprocessual ou extraprocessual, importando que sobre ele recaia hipótese normativa processual, o que acarretará em consequências jurídicos no bojo do processo. BRAGA, Paula Sarno. Primeiras reflexões sobre uma teoria do fato jurídico processual: plano da existência. Revista de Processo, São Paulo, v. 148, p.293-320, jun. 2007. P. 9.
} 
Já os negócios jurídicos processuais, tratando-se de “produto da autonomia privada ou da autorregulação de interesses, implicando liberdade de celebração e de estipulação" ${ }^{18}$, poderão ser realizados dentro ou fora do processo, de forma típica, quando estiverem previstos na legislação, ou de forma atípica, quando seu regime não estiver estipulado em lei. Este último tipo, novidade positivada pelo Código de Processo Civil de 2015 em seu artigo 190, será melhor tratado nos tópicos seguintes.

\section{CLÁUSULA GERAL DO ARTIGO 190 E A EFETIVIDADE DO PROCESSO}

Os negócios processuais típicos podem ser facilmente visualizados a partir da leitura dos artigos do Código de Processo Civil de 2015, como a eleição negocial do foro (art. 63, CPC), renúncia de prazo (art. 225, CPC), convenção sobre ônus da prova (art. $373 \S 3$ e 4, CPC), desistência de recurso (art. 999, CPC), entre outros.

Paralelamente, tem-se no caput do art. 190 do CPC "uma cláusula geral, da qual se extrai o subprincípio da atipicidade da negociação processual" ${ }^{\text {19 }}$, permitindo a convenção das partes acerca de mudança do procedimento, bem como seus ônus, poderes, faculdades e deveres processuais, o que foi, inclusive, tratado nos enunciados $257^{20}$ e $258^{21}$ do Fórum Permanente de Processualistas Civis.

A celebração destes acordos "atípicos" entre as partes, com base no princípio da adaptabilidade procedimental e de técnicas de flexibilização de procedimento, legitima a possibilidade de talhar o processo em face da especificidade da causa, empoderando as partes para que busquem um tratamento diferenciado dentro do processo em que litigam ${ }^{22} 23$.

Referido artigo harmoniza com a busca pela solução consensual do litígio pelas partes ao permitir o exercício das faculdades processuais conforme sua conveniência e prescindindo de homologação judicial para constituição, modificação ou extinção dos direitos processuais, o

\footnotetext{
${ }^{18}$ CUNHA, Leonardo Carneiro da. Negócios jurídicos processuais no processo civil brasileiro. In: CABRAL, Antonio do Passo; NOGUEIRA, Pedro Henrique (Org.). Negócios processuais. 3. ed. Salvador: Juspodivm, 2017, p. 39-74.

${ }^{19}$ DIDIER JUNIOR, Fredie. Negócios jurídicos processuais atípicos no CPC-2015. In: CABRAL, Antonio do Passo; NOGUEIRA, Pedro Henrique (Org.). Negócios processuais. 3. ed. Salvador: Juspodivm, 2016, p. 109.

20 257. (art. 190) O art. 190 autoriza que as partes tanto estipulem mudanças do procedimento quanto convencionem sobre os seus ônus, poderes, faculdades e deveres processuais.

${ }^{21}$ 258. (art. 190) As partes podem convencionar sobre seus ônus, poderes, faculdades e deveres processuais, ainda que essa convenção não importe ajustes às especificidades da causa.

${ }^{22}$ NOGUEIRA, Pedro Henrique. Sobre os acordos de procedimento no processo civil brasileiro. In: CABRAL, Antonio do Passo; NOGUEIRA, Pedro Henrique (Org.). Negócios processuais. 3. ed. Salvador: Juspodivm, 2017, p. 93-104.

${ }^{23}$ CAMBI, Eduardo; NEVES, Aline Regina das. Flexibilização procedimental no novo código de processo civil. Revista de Direito Privado, São Paulo, v. 64, p.219-259, out, 2015.
} 
que é acentuado, ainda, em face da notável impossibilidade do legislador prever todos as disciplinas jurídicas necessárias à busca da efetividade do direito material postulado ${ }^{24}$.

Empregando Fredie Didier "não se trata de negócio sobre o direito litigioso - essa é a autocomposição, já bastante conhecida. No caso, negocia-se sobre o processo, alterando suas regras, e não sobre o objeto litigioso do processo" 25 .

Rosa Maria de Andrade Ney ao tratar sobre o artigo instituidor da cláusula geral para negócios jurídicos dispõe que:

\begin{abstract}
"certas matérias de ordem pública, que não têm natureza jurídica de direitos patrimoniais de caráter privado, desde que tratadas pelos seus titulares, plenamente capazes, alusivas ao iter procedimental de ações que versam sobre direitos que admitem autocomposição, podem ser objeto de ajuste das partes, pois - pelo novo CPC - as partes podem, em comum acordo, em contrato anterior, ou no curso da demanda, inserir no rol das questões negociadas, o ajuste de procedimento processual, de acordo com a especificidade de seus interesses, convencionando sobre ônus, poderes, faculdades e deveres processuais, antes ou durante o processo (art. 190 do $\mathrm{CPC} / 2015)^{n 26}$.
\end{abstract}

É claro que, não obstante tratar-se de cláusula geral, o caput do artigo 190 não visa dotar as partes de poderes que lesem direito de outrem, de forma que, nas palavras de Pedro Henrique Nogueira, "o pacto somente será admitido (a) quando se tratar de direitos passíveis de autocomposição; (b) quando as partes sejam capazes e (c) quando estejam em situação de equilíbrio, não se permitindo o acordo de procedimento em contratos de adesão ou em contratos em que figurem partes em situação de vulnerabilidade" 27 .

Ainda, todavia a desnecessidade de homologação judicial, nota-se que a validade dos negócios jurídicos processuais deverá ser controlada pelo juiz, que lhe dará cumprimento quando válida a convenção ${ }^{28}$.

Ao tratar sobre essa permissão contratual como reforço da lógica do princípio in dubio pro libertate, Antonio do Passo Cabral dispõe em sua obra Convenções Processuais ${ }^{29}$ sobre as vantagens e desvantagens da cláusula geral de convencionalidade no processo brasileiro, o que merece acolhimento especial.

\footnotetext{
${ }^{24}$ NOGUEIRA, op. cit., p. 91-104.

${ }^{25}$ DIDIER JUNIOR, Fredie. Princípio do respeito ao autorregramento da vontade no processo civil. In: CABRAL, Antonio do Passo; NOGUEIRA, Pedro Henrique (Org.). Negócios processuais. 3. ed. Salvador: Juspodivm, 2017, p. 31-37.

${ }^{26}$ NERY, Rosa Maria de Andrade. Fatos processuais. Atos jurídicos processuais simples. Negócio jurídico processual (unilateral e bilateral). Transação. Revista de Direito Privado, São Paulo, v. 64, p.261-274, out. 2015. ${ }^{27}$ NOGUEIRA, Pedro Henrique. Sobre os acordos de procedimento no processo civil brasileiro. In: CABRAL, Antonio do Passo; NOGUEIRA, Pedro Henrique (Org.). Negócios processuais. 3. ed. Salvador: Juspodivm, 2017, p. 103.

${ }^{28}$ MEDINA, José Miguel Garcia. Curso de direito processual civil moderno. 3. ed. São Paulo, 2017.

${ }^{29}$ CABRAL, Antonio do Passo. Convenções processuais. 2. ed. Salvador: Juspodivm, 2018.
} 
Em se tratando de suas vantagens, em primeiro lugar trata que o artigo 190 sabiamente acabou com o debate sobre a possibilidade ou não de serem realizadas convenções processuais, tendo em vista que parte da doutrina ainda insistia em sua não admissão no tocante ao artigo 158 do $\mathrm{CPC} / 1973$.

Ainda, dispõe que "a correta percepção do permissivo genérico do art. 190 pode ter como consequência evidenciar o desequilíbrio que as derivações do publicismo geraram no direito processual brasileiro ${ }^{30}$ dando uma nova perspectiva a participação das partes no processo, principalmente aos poderes do juiz.

Outra importante vantagem apontada pelo autor é que a partir da cláusula geral a autonomia das partes não se restringirá ao expressamente previsto em lei, atribuindo uma "maior maleabilidade ao sistema, deixando margens de interpretação mais amplas para a jurisprudência e para a doutrina" ${ }^{31}$, de forma que a partir dessa consequente "generalização do suposto normativo" ${ }^{32}$, diversas novas interpretações da norma nascerão.

Não obstante as diversas vantagens sobre a cláusula geral na visão de Antonio do Passo Cabral, esse mesmo autor relata a dificuldade na interpretação da cláusula em vista da vagueza do texto, o que de certo dificultará a aplicação da norma e poderá gerar insegurança jurídica.

\section{A PREVAlênCia do AUTORRegramento da VONTAde NO CÓdigo DE PROCESSO CIVIL}

O Código de Processo Civil de 2015 ao possibilitar a adaptação dos procedimentos à especificidade do caso e às necessidades das partes, rompe com um modelo rígido de legalidade das formas que criava critérios preordenados no processo para passar a buscar eficácia na tutela jurisdicional e assegurar o acesso à justiça ${ }^{33}$.

Esta nova visão processual advém do fato de que as regras processuais não necessariamente adequam-se à tutela do direito material objeto do litígio e as necessidades dos sujeitos processuais, devendo haver uma relativização da norma cogente ${ }^{34}$. Neste sentido, cita Murilo Teixeira Avelino que "se ao processo cabe a função de concretização dos direitos materiais, o direito material põe-se como o valor regente da criação, interpretação e aplicação das regras de processo" ${ }^{\text {"35 }}$.

\footnotetext{
${ }^{30}$ CABRAL, Antonio do Passo. Convenções processuais. 2. ed. Salvador: Juspodivm, 2018, p. 166.

${ }^{31}$ Ibid.

${ }^{32}$ Ibid., p. 167.

${ }^{33}$ CAMBI, Eduardo; NEVES, Aline Regina das. Flexibilização procedimental no novo código de processo civil. Revista de Direito Privado, São Paulo, v. 64, p.219-259, out, 2015.

${ }^{34}$ AVELINO, Murilo Teixeira. A posição do magistrado em face dos negócios jurídicos processuais. Revista de Processo, São Paulo, v. 246, p.219-238, ago. 2015.

${ }^{35}$ Ibid.
} 
É neste sentido que o legislador do Código de Processo Civil de 2015, na busca de um processo mais célere e eficaz, rompe com o enclausuramento das partes à forma e inspirado por preceitos de cooperação, propõe o princípio do respeito ao autorregramento da vontade no processo civil.

Este princípio, segundo Didier:

\begin{abstract}
"visa, enfim, à obtenção de um ambiente processual em que o direito fundamental de autorregular-se possa ser exercido pelas partes sem restrições irrazoáveis ou injustificadas. De modo mais simples, esse princípio visa tornar o processo jurisdicional um espaço propício para o exercício da liberdade" 36.
\end{abstract}

Esta nova sistemática processual aliada à cláusula geral de atipicidade dos negócios jurídicos processuais prevista no art. 190 do CPC/2015, em conjunto com o art. 200 do CPC/2015, dá ampla liberdade às partes para celebração de convenções processuais que terão efeito imediato, salvo quando a lei exigir a homologação judicial ${ }^{37}$.

Reconhecendo as partes do processo como titulares de determinadas situações processuais, tem-se que o princípio do autorregramento da vontade no processo deve ser regra geral a ser observada pelo magistrado, que poderá exercer o controle de validade para o reconhecimento de eventuais nulidades ${ }^{38}$.

Bruno Garcia Redondo conceitua referido princípio da seguinte forma:

"eficácia imediata das declarações unilaterais ou bilaterais de vontade das partes, capazes de produzir, de plano, a constituição, a modificação ou a extinção de direitos processuais, independentemente de homologação pelo juiz, ao qual é permitido o controle somente a posteriori e restrito aos defeitos relativos aos planos da existência e da validade das convenções"39.

Aprofundando-se sobre o tema, Antonio do Passo Cabral dispõe que o princípio do respeito ao autorregramento da vontade trata-se de novo princípio advindo da combinação de dois outros: o princípio dispositivo e princípio do debate..$^{40}$

Neste sentido, enquanto o princípio dispositivo trata acerca da possibilidade de disposição da parte sobre o direito material, o princípio do debate autoriza as partes a

\footnotetext{
${ }^{36}$ DIDIER JUNIOR, Fredie. Princípio do respeito ao autorregramento da vontade no processo civil. In: CABRAL, Antonio do Passo; NOGUEIRA, Pedro Henrique (Org.). Negócios processuais. 3. ed. Salvador: Juspodivm, 2017, p. 35 .

37 REDONDO, Bruno Garcia. Negócios processuais: necessidade de rompimento radical com o sistema do CPC/1973 para a adequada compreensão da inovação do CPC/2015. In: CABRAL, Antonio do Passo; NOGUEIRA, Pedro Henrique (Org.). Negócios processuais. 3. ed. Salvador: Juspodivm, 2017, p. 391-400.

${ }^{38}$ Ibid.

${ }^{39}$ Ibid., p. 397.

${ }^{40}$ CABRAL, Antonio do Passo. Convenções processuais. 2. ed. Salvador: Juspodivm, 2018.
} 
conduzirem os procedimentos de acordo com o direito material postulado, de forma que, conjuntamente, ambos os princípios justificam a autonomia das partes consubstanciada no autorregramento da vontade ${ }^{41}$.

Tem-se, portanto, que referido princípio reafirma a noção de autonomia e cooperação instituída pelo Código de Processo Civil de 2015, dando às partes o protagonismo do processo, de forma que, nas palavras de Didier "a vontade das partes é relevante e merece respeito" ${ }^{2}$.

\section{NEGÓCIO PROCESSUAL E A INTERAÇÃO ENTRE O DIREITO MATERIAL E O PROCESSUAL}

As convenções sobre matérias processuais não devem ser confundidas com as convenções sobre direito materiais, não encontrando relação direta com os institutos da conciliação, mediação, e também com a arbitragem, já que os atos processuais produzirão efeitos diversos daqueles que envolvam diretamente o direito material.

Contudo, mesmo sendo independentes, em regra, estes institutos não podem ser vistos de forma totalmente apartada, já que comumente as especificidades do direito material postulado influirão sobre os negócios processuais, limitando-os ${ }^{43}$.

Em sua formação, tem-se que aos negócios jurídicos processuais aplicar-se-á não somente as normas de direito público das relações processuais, que regulamentarão a capacidade, forma, pressupostos processuais, etc, mas não há que se deixar de lado a teoria geral dos negócios, regulada pelo direito civil, aplicando-se, assim, normas de direito privado, já que, por muitas vezes, os negócios jurídicos são realizados extrajudicialmente, firmados previamente ao surgimento do processo ${ }^{44}$.

Para Fabio Caldas, a distinção entre o negócio jurídico e o negócio processual se faz necessária para a impugnação dos negócios jurídicos processuais, dispondo que sua diferença se funda na constituição dos institutos, haja vista que os negócios processuais nascem do acordo entre as partes, mas se constituem e exercem sua eficácia no processo, o que não significa que não se utilize do direito material para sua formação ${ }^{45}$.

\footnotetext{
41 Ibid.

${ }^{42}$ DIDIER JUNIOR, Fredie. Princípio do respeito ao autorregramento da vontade no processo civil. In: CABRAL, Antonio do Passo; NOGUEIRA, Pedro Henrique (Org.). Negócios processuais. 3. ed. Salvador: Juspodivm, 2017, p. 35 .

${ }^{43}$ CABRAL, Antonio do Passo. Convenções processuais. 2. ed. Salvador: Juspodivm, 2018.

${ }^{44}$ Ibid.

${ }^{45}$ ARAUJO, Fabio Caldas de. Curso de processo civil: Tomo I - arte geral - Atualizado com a lei 13.256/2016. São Paulo: Malheiros, 2016, p. 1048.
} 
Neste ponto, no negócio processual o juiz tem condições de realizar o controle sobre sua aplicação em virtude deste nascer dentro de uma relação processual, enquanto que nos acordos realizados anteriores ao processo e implementados em juízo, seu controle de validade deverá ser realizado a partir do direito material ${ }^{46}$.

Um exemplo do contato entre o direito material e processual para controle dos negócios processuais é a transação (art. 487, III, “b” do CPC), pontuando Fabio Caldas que:

\begin{abstract}
“embora a transação seja regulada pelos dispositivos do direito material, sua aplicação e sua homologação dentro do processo sujeitam-na aos requisitos da lei processual. Por este motivo, uma transação homologada em audiência de conciliação na qual apenas uma das partes está acompanhada por advogado deve ser considerada negócio processual nulo, pela ausência de capacidade postulatória, que é essencial para pôr fim à relação processual. Da mesma forma a homologação de um negócio processual que envolva prejuízo manifesto para uma das partes deve ser recusada, ante a configuração de negócio com conteúdo abusivo, especialmente quando uma das partes seja hipossuficiente" ${ }^{\prime 4}$
\end{abstract}

Para o controle dos negócios processuais Cabral defende que "deve haver uma corregulação entre normas materiais e processuais, que se combinam na normatização dos acordos processuais" ${ }^{\text {" }}$, de forma que não haverá uma subordinação entre as regras destes institutos, mas sua complementação.

Ainda, é possível que as normas entre direito material e processual se choquem quando operadas simultaneamente frente aos negócios processuais, de forma que, pela inexistência de hierarquia entre os institutos, é necessária essa corregulação entre as normas de acordo com a manifestação da vontade das partes ${ }^{49}$.

\title{
6 LIMITES DO NEGÓCIO JURÍDICO PROCESSUAL E A VINCULAÇÃO DO JUÍZO
}

Dentro dessa perspectiva de alteração dos procedimentos e adequação as especificidades da causa, o processo civil, ultrapassando sua fase instrumentalista, adquire um novo status caracterizado pelo diálogo entre os participantes, o status de processo cooperativo ${ }^{50}$ Essa noção de cooperação processual se complementa com o dever de lealdade entre as partes na busca de uma solução efetiva da lide. "é como se as pretensões resistidas que fomenta a lide

\footnotetext{
${ }^{46}$ ARAUJO, Fabio Caldas de. Curso de processo civil: Tomo I - arte geral - Atualizado com a lei 13.256/2016.

São Paulo: Malheiros, 2016, p. 1048.

${ }^{47}$ Ibid., p. 753

${ }^{48}$ CABRAL, Antonio do Passo. Convenções processuais. 2. ed. Salvador: Juspodivm, 2018, p. 287.

${ }^{49}$ Ibid.

${ }^{50}$ AVELINO, Murilo Teixeira. A posição do magistrado em face dos negócios jurídicos processuais. Revista de Processo, São Paulo, p.219-238, ago. 2015.
} 
fosse revisitada pela cláusula geral que inspira o dever de lealdade de posturas equilibradas das partes: não pretender tanto e não resistir com tanto vigor" ${ }^{\text {"1 }}$.

É nesse contexto que o papel das partes na busca da prestação jurisdicional deve ser revisitado, principalmente a atuação do juiz, que deixa de ser visto somente como uma autoridade que manifesta o direito, passando a recepcionar as partes no processo para que lhe auxiliem a encontrar o direito, havendo, assim, uma "ampliação qualitativa e quantitativa da função jurisdicional”, ${ }^{52}$.

Nessa nova sistemática em busca de um maior diálogo processual, o princípio do contraditório exige que tanto os atos das partes quanto do juiz sejam motivados e contem com o diálogo e participação dos sujeitos processuais, inclusive do juiz, que é retirado de sua posição de "expectador do embate livre entre as partes exercendo mero papel de mediador" ${ }^{53} \mathrm{e}$ é colocado em posição simétrica com as demais partes.

Importante pontuar que o contraditório tradicionalmente se limitava à cientificação das partes dos atos processuais, oportunizando-lhes a participação no processo, no entanto, na nova sistemática processual é possível verificar um contraditório robusto, ostentando uma ampla contraditoriedade e possibilitando as partes participarem efetivamente da construção da decisão judicial $^{54}$.

Tratando sobre essa sistemática, Murilo Teixeira Avelino trata que: "com a expansão do seu conteúdo, o contraditório passa a abarcar diversos elementos
de participação do processo, trazendo o juiz para o debate processual no mesmo
degrau das partes. Superada está a ideia de que às partes só cabe tratar de questões de
fato e que ao juiz somente de questões de direito, o processo se abre ao dialogo
processual em todas as suas instancias, sobre todas as matérias ali envolvidas"

O fortalecimento do contraditório nos negócios processuais é de bom tom sob o prisma de que devem as partes serem consultadas acerca dos objetivos do negócio jurídico formulado, sendo dever do magistrado preservar as convenções processuais que manifestam vontade livre entre as partes, partindo do princípio de que a transação a todos beneficia, de forma que sua

\footnotetext{
${ }^{51}$ NERY, Rosa Maria de Andrade. Fatos processuais. Atos jurídicos processuais simples. Negócio jurídico processual (unilateral e bilateral). Transação. Revista de Direito Privado, São Paulo, v. 64, p.261-274, out. 2015. 52 NERY, Rosa Maria de Andrade. Fatos processuais. Atos jurídicos processuais simples. Negócio jurídico processual (unilateral e bilateral). Transação. Revista de Direito Privado, São Paulo, v. 64, p.261-274, out. 2015. ${ }^{53}$ AVELINO, Murilo Teixeira. A posição do magistrado em face dos negócios jurídicos processuais. Revista de Processo, São Paulo, v. 246, p.219-238, ago. 2015, p. 222.

${ }^{54}$ CUNHA, Leonardo Carneiro da. O princípio do contraditório e a cooperação no processo. 2013. Disponível em: $\quad<$ https://www.leonardocarneirodacunha.com.br/artigos/o-principio-contraditorio-e-a-cooperacao-noprocesso/>. Acesso em: 11 mar. 2019.

${ }^{55}$ AVELINO, op. cit., p. 222-223.
} 
invalidade sem sua previa manifestação não condiz com os preceitos de negociação e cooperação que regem o Código de Processo Civil.

O texto expresso no art. 190 do CPC/2015, considerado uma cláusula geral para negócios jurídicos processuais, autoriza as partes a tratarem certas matérias de ordem pública como se privadas fossem, ou seja, podendo transacionar sobre elas de acordo com as especificidades da causa, mas desde que admitam a autocomposição.

O caput do diploma legal expressa quais os requisitos de validade dos negócios jurídicos processuais, consistentes i) na plena capacidade das partes; ii) em objeto lícito, possível, determinado ou determinável; e iii) na forma prescrita ou não defesa em lei, devendo o juiz observar os requisitos de validade dos negócios jurídicos (arts. 104 e 166 do Código Civil) e também aqueles inerentes ao processo civil.

Não observados estes requisitos, deverá o magistrado, nos termos do parágrafo único deste artigo, controlar a validade dos negócios processuais formulados e recusar-lhe aplicação nos casos de nulidade ou ante a situação de vulnerabilidade de uma das partes em face da outra.

Esta atuação do juiz é respaldada no art. 139 do CPC, que lhe atribui a direção do processo, o que, para Medina, poderá ser formal ou material. Formal em vista da determinação dos andamentos processuais, consubstanciado no princípio do impulso oficial. Material pelo fato de que não pode o magistrado manter-se inerte à condição das partes, devendo zelar pela isonomia processual e contraditório ${ }^{56}$.

O art. 139 do CPC reflete a concepção de participação ativa do juiz na condução da relação processual, que sendo gestor da relação processual, deverá agir em conjunto com as partes, observando sempre o tratamento isonômico entre elas, buscando a otimização na pratica dos atos processuais e incentivando a autocomposição para a o alcance da tutela jurisdicional $\operatorname{adequada}^{57}$

Contudo, há ampla controvérsia doutrinária no tocante a participação do juiz como sujeito do negócio processual, ao passo que o art. 190 do CPC trata somente de seu controle pelo magistrado, especialmente em seu parágrafo único, aonde se reforça o controle das invalidades.

Esse controle pelo juiz visa analisar se as convenções tratam sobre direitos que admitem a autocomposição, tendo em vista a limitação do direito de formular acordos sobre

\footnotetext{
${ }^{56}$ MEDINA, José Miguel Garcia. Curso de direito processual civil moderno. 3. ed. São Paulo, 2017.

${ }^{57}$ ARAUJO, Fabio Caldas de. Curso de processo civil: Tomo I - arte geral - Atualizado com a lei 13.256/2016. São Paulo: Malheiros, 2016, p. 1048.
} 
objetos indisponíveis, em manutenção da postura protetiva e cogente assumida pelo legislador ${ }^{58}$.

É neste sentido que Fabio Caldas de Araújo ao tratar sobre o caráter cogente da norma jurídica e os limites dos negócios processuais quando o direito material admitir a autocomposição dispõe que "a disponibilidade do direito não representa uma carta branca para modular o processo. Ela abrirá uma grande margem de adaptação do procedimento e do uso das faculdades com o fim de permitir solução adequada para as partes" ${ }^{\$ 9}$.

Antonio do Passo Cabral, utilizando-se da "Teoria pura do direito" de Hans Kelsen, dispõe que a vontade do juiz não se soma à dos interessados na celebração do acordo, pois "a capacidade negocial não é própria da função jurisdicional" ${ }^{\circ 0}$, de forma que somente as partes interessadas na solução do direito material podem transigir, o que se contrapõe à atuação imparcial do juiz que não teria autonomia, somente podendo atuar no controle de validade das convenções processuais $^{61}$.

$\mathrm{O}$ autor continua seu posicionamento dispondo que a atuação do juiz frente aos negócios processuais se limita a duas: i) Incentivar o diálogo para formação dos negócios processuais, esclarecendo-os e indicando suas vantagens e desvantagens, e ii) Controlar ou fiscalizar os acordos processuais, analisando sua validade e conveniência ${ }^{62}$.

Em contraponto, Humberto Teodoro Júnior defende que os negócios processuais não se vinculam a análise de conveniência pelo juiz, o qual deverá restringir sua análise à validade do acordo firmado ${ }^{63}$.

Tem-se, assim, que o entendimento doutrinário acerca dos poderes do juiz frente aos negócios processuais não é unânime, de forma que passa-se a tratar especificamente acerca da atuação do juiz como fiscal e como parte do acordo processual.

\subsection{JUIZ COMO FISCAL DO NEGÓCIO JURÍDICO PROCESSUAL}

Dentre os negócios processuais realizados pelas partes e que não contam com a participação do magistrado, ou seja, não é classificado como parte, é possível pontuar a

\footnotetext{
58 Ibid.

${ }^{59}$ ARAUJO, Fabio Caldas de. Curso de processo civil: Tomo I - arte geral - Atualizado com a lei 13.256/2016. São Paulo: Malheiros, 2016, p. 755.

${ }^{60}$ CABRAL, Antonio do Passo. Convenções processuais. 2. ed. Salvador: Juspodivm, 2018, p. 252.

61 Ibid.

${ }^{62}$ Ibid.

63 THEODORO JUNIOR, Humberto. Curto de direito processual civil: teoria geral do direito processual civil, processo de conhecimento e procedimento comum. 58. ed. Rio de Janeiro: Forense, 2017, v. 1.
} 
competência relativa (art. 63 CPC), escolha consensual do perito (art. 468 do CPC), convenções sobre o momento dos atos processuais (art. $364 \S 1$, art. 313, II, art. 362, I do CPC), convenção de distribuição do ônus da prova (art. 343 § 3 do CPC), entre outras hipóteses em que é necessária a homologação.

Nestas hipóteses o magistrado atua tão somente como verificador da validade dos negócios jurídicos, verificando sua adequação com o ordenamento, ${ }^{64}$ recusando-lhes aplicação em caso de invalidade ou abusividade, assim como preceitua caput do art. 190 do CPC, homologando-o quando o exercício do autorregramento da vontade estiver em consonância com os requisitos de validade dos negócios jurídicos.

Nestes casos, a homologação judicial trata-se de condição de eficácia do negócio jurídico celebrado entre as partes, dando-lhe eficácia ${ }^{65}$.

Ainda, nos termos do enunciado 261 do Fórum Permanente de Processualistas Civis ${ }^{66}$ cabe ao juiz verificar a capacidade das partes regularem o procedimento.

Murilo Teixeira Avelino ao tratar sobre o assunto dispõe que:

\begin{abstract}
"quando se exige a homologação, o juiz atua somente para permitir que o negócio produza os seus efeitos específicos no processo, funcionando a atuação do juiz como conditio iuris para a eficácia do ato; na hipótese geral de negócios sobre o procedimento, a disposição das partes presume-se válida, cabendo ao juiz somente atuar no controle de validade do ato" ${ }^{\prime 67}$.
\end{abstract}

Já para Cabral o juiz se vincula às convenções processuais, mas não em virtude de uma declaração de vontade estatal, mas de uma "heterolimitação da atuação judicial, incidente sobre os atos e formalidades do processo, operada pelo atuar legítimo das partes no espaço de autonomia que o ordenamento processual lhes assegura" $"$.

A função de controlador ou fiscalizador do juiz surge a partir de sua função de zelar pelo interesse público, evitando que a autonomia exercida pelas partes extrapolem o espaço que lhes foi dado pelo ordenamento jurídico, de forma que "o juiz se vincula sim, mas apenas aos acordos processuais válidos" ${ }^{\prime 9}$.

De forma contrária entende Murilo Teixeira Avelino, que interpreta a emissão volitiva do juiz para homologação dos acordos processuais, controlando sua validade, como negócios

\footnotetext{
${ }^{64}$ AVELINO, Murilo Teixeira. A posição do magistrado em face dos negócios jurídicos processuais. Revista de Processo, São Paulo, v. 246, p.219-238, ago. 2015.

${ }^{65}$ CABRAL, Antonio do Passo. Convenções processuais. 2. ed. Salvador: Juspodivm, 2018.

${ }^{66} 261$. (arts. 190 e 200) O art. 200 aplica-se tanto aos negócios unilaterais quanto aos bilaterais, incluindo as convenções processuais do art. 190. (Grupo: Negócios Processuais)

${ }^{67}$ AVELINO, op. cit., p. 225-226.

${ }^{68}$ CABRAL, op. cit., p. 256.

${ }^{69}$ Ibid., p. 529.
} 
processuais plurilaterais, já que exigem tanto a manifestação de vontade das partes quanto do próprio juiz ${ }^{70}$.

Nessa premissa, o juiz seria um co-declarante do negócio jurídico processual, o que só será possível dentro dos negócios jurídicos processuais típicos ${ }^{71}$.

Contudo, há também hipóteses em que as partes opõe ao próprio negócio jurídico a condicionante de homologação, de forma que a eficácia vinculada a homologação não decorre de lei, mas do próprio negócio jurídico ${ }^{72}$.

\subsection{JUIZ COMO SUJEITO DO NEGÓCIO JURÍDICO PROCESSUAL}

Ao contrário das situações em que cumpre ao juiz a regulação do negócio processual, há também hipóteses em que o magistrado atua como parte da relação processual, sendo imprescindível para caracterização do negócio processual sua manifestação ${ }^{73}$.

Murilo Teixeira Avelino trata como fonte da capacidade negocial do magistrado o princípio da adequação que, extraído do processo legal, fundamenta a adaptação do procedimento na busca da mais correta aplicação da tutela jurisdicional, citando que:

\footnotetext{
“o juiz é destinatário direto do princípio da adequação, admitindo-se que, junto às partes, seja sujeito de negócios processuais atípicos, propondo-os inclusive, caso observe a necessidade de superação do procedimento regular, em prol da prestação de uma tutela jurisdicional efetiva, eficiente e adequada. Está aí, no princípio da adequação, a base de fundamentação da capacidade negocial ampla do magistrado"74.
}

A adaptação do procedimento, que dar-se-á primeiramente pelo legislativo através da elaboração de leis, alcança ao magistrado ao passo que poderá dentro dos limites estabelecidos em lei, alterar os procedimentos para adequá-los ao caso concreto, flexibilizando-os ${ }^{75}$.

Nestes termos, havendo a possibilidade de flexibilização do procedimento pelo juiz que, em paridade com as partes processuais poderá tratar sobre o procedimento na busca da eficiência do processo, não há que se falar em sua atuação somente como fiscal da lei ou

\footnotetext{
${ }^{70}$ AVELINO, op. cit.

${ }^{71}$ AVELINO, Murilo Teixeira. A posição do magistrado em face dos negócios jurídicos processuais. Revista de Processo, São Paulo, v. 246, p.219-238, ago. 2015.

${ }^{72}$ CABRAL, Antonio do Passo. Convenções processuais. 2. ed. Salvador: Juspodivm, 2018.

73 AVELINO, op. cit.

${ }^{74}$ Ibid., p. 419.

75 GAJARDONI, Fernando da Fonseca; SOUZA, Maurício Bearzotti de. Os princípios da adequação, da adaptabilidade e da flexibilização procedimental pelo juiz no novo CPC. Revista do Tribunal Superior do Trabalho, São Paulo, v. 82, p.165-187, jul, 2016.
} 
verificador da validade do negócio processual, o que contrapõe com o marco do processo cooperativo e a noção de diálogo processual.

Defendendo a participação do juiz como parte do negócio processual, Fredie Didier Jr divide os negócios processuais em unilaterais, bilaterais e plurilaterais, tratando os unilaterais como aqueles que manifestam a vontade de uma só parte, os bilaterais como aqueles que manifestam de duas vontades e os plurilaterais como aqueles firmados pela vontade de mais de dois sujeitos, envolvendo nesta hipótese, a participação também do juiz ${ }^{76}$.

Os chamados negócios jurídicos processuais plurilaterais devem sempre estar devidamente expressos em lei, ou seja, são típicos, já que enquanto cumpre às partes titularizar situações processuais que envolvam direitos processuais e materiais, ao magistrado cumpre tão somente versar sobre o processo, já que não é titular do direito material ${ }^{77}$, como por exemplo o saneamento consensual (art. 357 § 2 CPC), calendário processual (art. 191 § 1 CPC), casos em que a "emissão volitiva é elemento do plano da validade, que só se preenche a partir de sua efetiva participação"78.

Para Fredie Didier Jr, não há que se negar a participação do juiz nas negociações típicas mesmo que nos termos do art. 190 só se faça menção aos negócios processuais atípicos celebrados pelas partes, tendo em vista que o próprio sistema processual prevê a participação do juiz como participante da relação negocial, como nos casos do calendário processual e ainda pelo falo que de que não há prejuízos na participação do juiz, que de pronto estará validando a negociação processual ${ }^{79}$.

O calendário processual, previsto no artigo 191 do CPC, é um grande exemplo de negócio processual que conta com a participação ativa não só das partes, mas também do juízo, tratando-se de modelo de gerenciamento processual compartilhado que altera a sistemática de controle dos cartórios e rompe com o monopólio do juiz na condução do processo e funda-se, precipuamente, "a aumentar a previsibilidade do procedimento, em reforço da segurança jurídica e da efetividade da prestação jurisdicional" ${ }^{\prime 80}$.

Nesta hipótese, por tratar-se de modelo que altera o procedimento comumente adotado na sistemática processualística, tirando não só as partes mas também o juízo dos confortáveis e

\footnotetext{
${ }^{76}$ DIDIER JR. Fredie. Curso de direito processual civil: introdução ao direito processual civil, parte geral e processo de conhecimento 17. ed. Salvador: Ed. Juspodvim, 2015.

${ }_{77}^{7 V}$ AVLINO, Murilo Teixeira. A posição do magistrado em face dos negócios jurídicos processuais. Revista de Processo, São Paulo, v. 246, p.219-238, ago. 2015.

${ }^{78}$ Ibid., p. 228.

${ }^{79}$ DIDIER JR. op. cit., p. 293-303.

${ }^{80}$ CUEVA, Ricardo Villas Bôas. Flexibilização do procedimento e calendário processual no novo CPC. In: CABRAL, Antonio do Passo; NOGUEIRA, Pedro Henrique (Org.). Negócios processuais. 3. ed. Salvador: Juspodivm, 2017, p. 527-539.
} 
elásticos prazos previstos em lei, a conversa entre todos os envolvidos se faz imprescindível, adotando-se, assim, o juiz como parte na negociação.

Outro exemplo de negócio jurídico processual que influencia na situação jurídica do juiz é o saneamento processual consensual, previsto no art. $357 \S 2$ do CPC, aonde as partes propõe o saneamento processual ao juiz que deverá manifestar-se a respeito como sujeito processual.

Murillo Teixeira Avelino defende a participação do juiz como sujeito do negócio processual formulado no saneamento consensual, dispondo que:

\footnotetext{
“para que o negócio seja plenamente válido, é necessário o encontro de vontades das partes e do magistrado, em típico ato negocial plurilateral, mormente porque, para que o juiz seja legitimamente "vinculado" ao saneamento consensual, é necessário que participe do saneamento consensual como sujeito do negócio" 81 .
}

O estudioso ainda traz que, ao utilizar-se da partícula "se" antes de "homologado", dispôs o legislador sobre a possibilidade do juiz não homologar o saneamento consensual, não obstante ser requisito para sua efetividade a manifestação do juízo ${ }^{82}$.

Tem-se, assim, a participação do juiz como parte processual também em negócios jurídicos processuais típicos, chamados aqui de plurilaterais, o que certamente não se exaure pelas hipóteses aqui apresentadas.

\section{CONCLUSÃO}

Após todo o exposto, conclui-se que as alterações legislativas provenientes da mudança na cultura processualística que viu a necessidade de dotar as partes de poderes dentro do processo, dando a elas a capacidade de regulamentação do procedimento de acordo com o direito material postulado, também exerceu forte influência na atuação do juiz dentro de demanda que para de atuar como simples fiscal da lei e passa a exercer o papel de sujeito da negociação processual em alguns casos.

É nestes termos que a participação do juiz como sujeito da relação processual é observada nas hipóteses em que a homologação da transação não for condicionante à produção de efeitos jurídicos, ou seja, nas hipóteses de negócios jurídicos processuais típicos, de forma

\footnotetext{
${ }^{81}$ AVELINO, Murilo Teixeira. A posição do magistrado em face dos negócios jurídicos processuais. Revista de Processo, São Paulo, v. 246, p. 219-238, ago. 2015, p. 420.

${ }^{82}$ Ibid.
} 
que entender de forma contrária retiraria das partes a liberdade que lhes foi concedida pelo legislador.

O posicionamento doutrinário sobre a atuação do juiz frente os negócios jurídicos processuais não é unanime, havendo ampla discussão acerca da classificação da atuação ativa do juiz e quais seus limites, o que não se exaure no presente estudo, não restando dúvidas acerca da importância do tema que visa, precipuamente, valorizar o diálogo entre as partes.

\section{REFERÊNCIAS}

ARAUJO, Fabio Caldas de. Curso de processo civil: Tomo I - arte geral - Atualizado com a lei 13.256/2016. São Paulo: Malheiros, 2016.

AVELINO, Murilo Teixeira. A posição do magistrado em face dos negócios jurídicos processuais. Revista de Processo, São Paulo, v. 246, p.219-238, ago. 2015.

BRAGA, Paula Sarno. Primeiras reflexões sobre uma teoria do fato jurídico processual: plano da existência. Revista de Processo, São Paulo, v. 148, p.293-320, jun. 2007.

CABRAL, Antonio do Passo. Convenções processuais. 2. ed. Salvador: Juspodivm, 2018.

CAMBI, Eduardo; NEVES, Aline Regina das. Flexibilização procedimental no novo código de processo civil. Revista de Direito Privado, São Paulo, v. 64, p.219-259, out, 2015.

CUEVA, Ricardo Villas Bôas. Flexibilização do procedimento e calendário processual no novo CPC. In: CABRAL, Antonio do Passo; NOGUEIRA, Pedro Henrique. Negócios processuais. 3. ed. Salvador: Juspodivm, 2017.

CUNHA, Leonardo Carneiro da. Negócios Jurídicos Processuais no Processo Civil Brasileiro. In: CABRAL, Antonio do Passo; NOGUEIRA, Pedro Henrique (Org.). Negócios processuais. 3. ed. Salvador: Juspodivm, 2017.

O princípio do contraditório e a cooperação no processo. 2013. Disponível em: $<$ https://www.leonardocarneirodacunha.com.br/artigos/o-principio-contraditorio-e-acooperacao-no-processo/>. Acesso em: 11 mar. 2019.

DIDIER JR, Fredie. Art. 90. In: STRECK, Lenio Luiz; NUNES, Dierle; CUNHA, Leonardo Carneiro da; (Org.) Comentários ao código de processo civil. São Paulo: Saraiva, 2016.

Curso de Direito Processual Civil: Introdução ao direito processual civil, parte geral e processo de conhecimento. 17. ed. Salvador: Ed. Juspodvim, 2015.

Negócios jurídicos processuais atípicos no CPC-2015. In: CABRAL, Antonio do Passo; NOGUEIRA, Pedro Henrique (Org.). Negócios processuais. 3. ed. Salvador: Juspodivm, 2017. 
. Princípio do respeito ao autorregramento da vontade no processo civil. In: CABRAL, Antonio do Passo; NOGUEIRA, Pedro Henrique (Org.). Negócios processuais. 3. ed. Salvador: Juspodivm, 2017.

GAJARDONI, Fernando da Fonseca; SOUZA, Maurício Bearzotti de. Os princípios da adequação, da adaptabilidade e da flexibilização procedimental pelo juiz no novo CPC. Revista do Tribunal Superior do Trabalho, São Paulo, v. 82, p.165-187, jul, 2016.

JUNIOR, Antonio Jorge Pereira; SANTOS, Vanessa Gonçalves Melo. O NEGÓCIO JURÍDICO PROCESSUAL ATÍPICO E SUA EFETIVIDADE APÓS UM ANO DE VIGÊNCIA DO NOVO CÓDIGO DE PROCESSO CIVIL. Revista Juridica, [S.1.], v. 2, n. 51, p. 211 - 229, abr. 2018. ISSN 2316-753X. Disponível

em: <http://revista.unicuritiba.edu.br/index.php/RevJur/article/view/2806/371371474>. Acesso em: 23 abr. 2020. doi:http://dx.doi.org/10.21902/revistajur.2316-753X.v51i2.2806.

MEDINA, José Miguel Garcia. Curso de direito processual civil moderno. 3. ed. São Paulo, 2017.

MELO, Marcos Bernardes de. Teoria do fato jurídico: plano da existência. 7. ed. São Paulo: Saraiva, 1995.

MIRANDA, Pontes de. Tratado de direito privado. 60. ed. Campinas: Bookseller, 2000.

NERY, Rosa Maria de Andrade. Fatos processuais. Atos jurídicos processuais simples. Negócio jurídico processual (unilateral e bilateral). Transação. Revista de Direito Privado, São Paulo, v. 64, p.261-274, out. 2015.

NOGUEIRA, Pedro Henrique. Sobre os Acordos de Procedimento no Processo Civil Brasileiro. In: CABRAL, Antonio do Passo; NOGUEIRA, Pedro Henrique (Org.). Negócios Processuais. 3. ed. Salvador: Juspodivm, 2017.

REDONDO, Bruno Garcia. Negócios processuais: necessidade de rompimento radical com o sistema do CPC/1973 para a adequada compreensão da inovação do CPC/2015. In: CABRAL, Antonio do Passo; NOGUEIRA, Pedro Henrique (Org.). Negócios processuais. 3. ed. Salvador: Juspodivm, 2017.

THEODORO JUNIOR, Humberto. Curso de direito processual civil: teoria geral do direito processual civil, processo de conhecimento e procedimento comum. 58. ed. Rio de Janeiro: Forense, 2017. v. 1. 